\title{
Is Intergenerational Inheritance of Family Business Promoting Innovation or Hindering Innovation?
}

\author{
-Debate and Integration
}

\author{
Jintao Yan * \\ Accounting College \\ Guangdong University of Finance and Economics \\ Guangdong, China, 510320
}

\author{
Kaiyan $\mathrm{He}$ \\ Accounting College \\ Guangdong University of Finance and Economics \\ Guangdong, China, 510320
}

\begin{abstract}
Clarifying the causes and factors that influenced the dispute between family business and innovation in family business, which can help us better explain the academic debate on the intergenerational inheritance and innovation of family business, and at the same time help to develop the intergenerational inheritance of family business. Firstly, the relevant literatures in recent years are sorted out, and the relationship between family business's intergenerational inheritance and innovation is summarized: promotion, inhibition or influenced by internal and external factors of the family. Secondly, this article is summarized: the intergenerational inheritance of family business may be a promoting effect or an inhibitory effect on innovation investment. And finally, corresponding opinions are put forward according to the conclusion. This paper proposes the research direction of family business innovation controversy by constructing contingency theory, which is helpful to enrich the research of family business in the field of intergenerational inheritance and innovation.
\end{abstract}

Keywords-family business; intergenerational inheritance; innovation

\section{INTRODUCTION}

Innovation is the fundamental driving force for the development of modern enterprises and the source of value creation. Private enterprises represented by family businesses occupy an important position in the national economy, both in developed countries and in developing countries.

Driven by the long-term orientation of entrepreneurship and long-term entrepreneurship, family businesses have been able to occupy an important seat in China's mixed ownership economy through continuous innovation and exploration. However, business owners are facing the problem of arranging follow-up managers due to natural reasons such as their physical or age, and the transformation of family businesses is imminent. The intergenerational inheritance of family business will become a hot spot for corporate practitioners and theoretical scholars 0 . Therefore, it is necessary to integrate and sort out the literature on intergenerational inheritance and innovation of family enterprises.

\section{The Dispute Between FAMily Business's INTERGENERATIONAL INHERITANCE AND INNOVATION INVESTMENT}

\section{A. The first view: intergenerational inheritance of family enterprises promotes innovation investment}

The intergenerational inheritance of family business is the core goal of the family business, and it is the most significant difference from other companies. Fan et al Error! Reference source not found.found that when the second generation takes over, the new business owners will reduce their reliance on relational contracts. $\mathrm{Xu}$ et al.(2015) found that when the second generation entered the family business, the company's short-selling behavior decreased and its performance improved.

Ayyagaril (2011) found that control families can improve corporate innovation activities, and external financing, highly educated managers and participation in foreign competition have a positive impact on this. Ashwin et al.(2015) and Chen et al. Error! Reference source not found. found that family businesses invest more in innovation than non-family businesses, this suggests that the motivation of family businesses to encourage innovation investment exceeds the risk diversification motivation of families when making innovative decisions. Duran et al. Error! Reference source not found.and Hsu et al.(2016) found that family firms had better innovation output. The reason is the long-term orientation of family business and the innovative spirit of business owners.

When the second generation of the family entered the company as a company executive, this behavior conveys to the outside world the signal that the company will operate for a long time, the family's willingness to inherit increases the innovation investment of the enterprise. At the same time, the long-term orientation of the entrepreneur will reduce the short-selling behavior of the major shareholders, and then carry out innovative activities and improve the efficiency of corporate innovation activities. Finally, the second generation of intervention is conducive to supervising the company's senior management personnel, reducing the first type of agency problems; at the same time, under the premise that the special assets such as political connections, bank-enterprise relations 


\section{B. The second view: the intergenerational inheritance of family enterprises inhibits the innovation investment of enterprises}

MASSIS A D et al. (2013) based on the perspective of inheritance, pointed out that intergenerational inheritance has a direct effect on the innovation investment and output of enterprises. Prugl et al. (2015) proposed a negative correlation between intergenerational authority and innovation. Matzler et al. (2015) and Classen et al. [4] also confirmed that family companies have relatively low innovation investment. LUBATKIN M H(2005) and Sanchez-Bueno(2011) also reached the same conclusion based on agency costs and resource endowments.

Zhao Jing et al (2016) empirical analysis analyzes the influence of heir's social capital on enterprise innovation in intergenerational inheritance. The research results show that intergenerational inheritance significantly reduces the level of family business innovation; with the richness of heirs' social capital, the level of enterprise innovation will be improved in intergenerational inheritance. The intergenerational differences in social capital have significantly reduced the level of innovation in intergenerational heritage enterprises. The legitimacy disadvantage of the heirs in intergenerational inheritance is an important reason for the family enterprise innovation strategy to be conservative. Strengthening the inheritor's social capital and narrowing the intergenerational differences of social capital is conducive to reducing the negative impact of intergenerational inheritance.

In the critical period of intergenerational inheritance, in order to reduce the loss of social emotional wealth [8], R\&D is reduced. And at the same time, the altruism of the family business will lead to a series of agency problems. Driven by altruism, the founders of the company may transfer funds through the misappropriation of enterprise resources, resulting in higher consumption rates and lower investment rates. The first generation is to make the second generation more convincing, and it may also manipulate financial profits by reducing $R \& D$ expenditures, so that relevant stakeholders will temporarily pay more attention to the short-term benefits of the inheritance period (2004).In short, family businesses generally show a tendency to risk aversion during the intergenerational inheritance phase, investing less R\&D funds.

The intergenerational inheritance of family businesses is not a simple father's withdrawal, but the late generation takes over, which is related to succession planning, succession selection, succession process, succession evaluation and other issues. Intergenerational inheritance is a process, not a simple event. Wang Xiangyao et al. [9] divided the family business inheritance process into three stages: participation management, joint management and acceptance management. It was found that the first two stages were less innovative; the final stage of enterprise innovation was improved. In the early stages of inheritance, family businesses with control tend to reduce the risks at this stage[2]. Most of the veteran people and prestigious early employees in the enterprise have a high degree of contractual psychology to entrepreneurs (2006), which makes them have no trust in the second generation successor, thus the psychological contract of the founder was destroyed. The "leadership" role characteristics such as management ability, leadership style and other personal characteristics and resource endowments are the basis for evaluating whether the heir is “qualified”. However, the second generation of heirs often shows a clear gap with a generation of inheritors in these aspects, which reduces the recognition of corporate stakeholders (especially members of the organization). Therefore, based on the risk aversion in the early stage of inheritance, and taking into account the lack of authority of the second generation of heirs, it is difficult to play the heterogeneity advantage, and the innovation ability of family enterprises in the stage of participation management may be weakened.

Compared with the second generation just involved in the management of the company, the second generation of authority has been upgraded in the joint management stage of the first generation and the second generation, but the situation of "less masters are difficult to serve the public" still exists [ ]. Therefore, the second generation often hopes to be able to make certain performances in the short term, and more importantly is the current interests of the enterprise, rather than tending to make long-term investments, so it will generate a "quick victory" motivation, which will lead to a decline in corporate resources in a short-term, quick-acting direction, and a reduction in innovation.[7].

\section{THE CONTINGENCY FACTORS AFFECTING THE INTERGENERATIONAL INHERITANCE AND INNOVATION OF FAMILY BUSINESS}

The intergenerational inheritance of family business is influenced by external and internal factors. This view is a contingent view that integrates the arguments of the above two types of views.

\section{A. The influence of internal factors on the disputes between family business and intergenerational inheritance and innovation}

Family long-term orientation. The founders founded the company is to hope that the company can be elders and passed down from generation to generation. Innovation is the inexhaustible driving force for a company to last forever. Whether the family business succeeds in the development of new products, the long-term orientation of entrepreneurs will promote the investment of family businesses in long-term activities, such as the development of new products. Kammerlander and Ganter (2015) through a longitudinal case study of the German consumer goods industry, it was discovered that the desire of family executives to transfer value across generations will promote the development of new technologies. The reason is that its fear of not taking action may jeopardize the consequences of its non-economic benefits.

2. Conservative and risk aversion. To maintain the stability and security of family assets, the family may lead to conservatism and risk aversion, hindering corporate innovation. Therefore, in order to ensure the safety of family wealth, based on the perspective of risk aversion, the control family tends to adopt a conservative strategy to limit corporate innovation investment. 
3. The interaction between the first generation and the second generation. The family leader inheritance stage is a particularly difficult period of innovation. The quantitative results of Hauck and Prugl (2015) show that family adaptability and value members are positively related to the company's intimacy and innovation opportunities, and intergenerational authority and value history have the opposite effect.

\section{B. The influence of external factors on the disputes between family business and intergenerational inheritance and innovation}

1. Institutional environment. Peng (2003) believes that any innovative behavior is carried out in a certain institutional environment, institutional environment is an important macro environmental factor affecting corporate behavior in transitional economy,. Li and Zhang (2007) argue that in some areas with poor institutional environment, especially in a bad competitive environment, family businesses are less innovative.

2. The degree of intellectual property protection. With the increasing role of intellectual property rights in international competition, the impact of intellectual property protection on corporate innovation has received increasing attention. Only when intellectual property rights are effectively protected, entrepreneurs are more inclined to achieve long-term sustainable development through enterprise innovation. Zhi T and Clyde H (2012) believe that the establishment of a clear property rights and patent protection system, the company's innovative spirit will be stronger.

3. Government policy. The amount of innovation invested by enterprises is inseparable from the government's policy support. LUBATKIN M H (2005) and Lin et al. (2010) pointed out that government policy support and a good service environment are important factors in promoting corporate R\&D activities.

\section{SUMMARY}

Through the above analysis, we can see that the current research literature on intergenerational inheritance and innovation of family enterprises is very rich, but the conclusions reached are significantly different, which leads to the study of the relationship between family business intergenerational inheritance and innovation. One controversy: Is the intergenerational inheritance of family business promoting enterprise innovation or inhibiting enterprise innovation? This paper focuses on the debate on family business innovation, combs and summarizes the relevant literature, and draws the following conclusions:

1. The results show that there is no uniform result of the influence of intergenerational inheritance of family business on innovation. It mainly uses agency theory and social emotional wealth theory to analyze and infer.

2. From an internal perspective: the long-term orientation of the family will promote the innovation investment of the enterprise, while the family risk aversion and relationship orientation will hinder the enterprise innovation.
3. From an external perspective: institutional environment, intellectual property protection and innovation policies are conducive to family business innovation.

Family business is a combination of family and business. In order to better develop the enterprise and strengthen the strength of the family business, innovative investment is indispensable.

First, in terms of internal factors, the intergenerational inheritance of family businesses reduces the first type of agency costs and promotes innovation; the conservative tendencies of enterprises and the "quick win" motives of successors will inhibit corporate innovation. In order to improve corporate innovation, companies should be alert to conservatism, improve the family's long-term orientation, and weaken the short-sighted behavior of the second generation.

Secondly, as far as the external environment is concerned, the institutional environment such as government policies and intellectual property protection will have different impacts on family businesses. Government departments should strengthen the protection of intellectual property rights and create a good environment for enterprise innovation.

Finally, in terms of the contingency theory framework, the influence of family internal and external environmental factors on family business innovation is complex. In order to better play the role of innovation, family businesses must fully consider the internal and external factors of the family and promote the organic integration of the two.

\section{REFERENCES}

[1] Chen Lin, Wang Hesen. Historical Development and Modern Transformation of Chinese Family Enterprises-A Sidelight on the 7th International Symposium on "Entrepreneurship and Family Business Growth" [J] Management World, 2012(4): 153-158. (In Chinese).

[2] Choi Y R, Zahra S A, Yoshikawa T, et al. Family ownership and R\&D investment: The role of growth opportunities and business group membership [J]. Journal of Business Research, 2015, 68(5): 1053-1061.

[3] Chen V Y S, Tsao S M, Chen G Z. Founding family ownership and innovation[J]. Asia-Pacific Journal of Accounting \& Economics, 2013, 20(4): 429-456.

[4] Classen N, Carree M, Van Gils A, et al. Innovation in family and non-family SMEs: An exploratory analysis[J]. Small Business Economics, 2014, 42(3): 595-609.

[5] Duran, P., Kammerlander, N., Van Essen, M., Zellweger, T.. Doing More with Less: Innovation Input and Output in Family Firms. Academy of Management Journal, 2016, 59(4): 1224-1264.

[6] Fan, J. P., Wong, T. J., Zhang, T.. Founder Succession and Accounting Properties. Contemporary Accounting Research, 2012, 29(1): 283-311.

[7] Li Xinchun, Han Jian, Li Yuwen's inheritance or another creation of territory?- the authoritative legality construction of the second generation inheritance of family business [J].Management World, 2015(6):110-124. (In Chinese).

[8] Wu Bingde, Chen Ling. Social Emotional Wealth and R\&D Investment Portfolio: The Influence of Family Governance[J].Science Research 2014 (8): 1233-1241.(In Chinese).

[9] Wang Xiangyao, Jin Yihe, Bi Wei. The intergenerational inheritance of family enterprises promotes or inhibits innovation [J]. Business Economics and Management, 2016(12): 73-82.(In Chinese) 